\title{
Editorial \\ Contemporary Teacher Education: A Global Perspective-Introduction to a Special Collection of Research
}

\author{
Kirsi Tirri (D) \\ Faculty of Educational Sciences, University of Helsinki, Yliopistonkatu 4, 00100 Helsinki, Finland; \\ kirsi.tirri@helsinki.fi
}

check for updates

Citation: Tirri, K. Contemporary

Teacher Education: A Global

Perspective-Introduction to a Special Collection of Research. Educ. Sci. 2021, 11, 340. https://doi.org/ 10.3390/educsci11070340

Received: 6 July 2021

Accepted: 6 July 2021

Published: 9 July 2021

Publisher's Note: MDPI stays neutral with regard to jurisdictional claims in published maps and institutional affiliations.

Copyright: (C) 2021 by the author. Licensee MDPI, Basel, Switzerland. This article is an open access article distributed under the terms and conditions of the Creative Commons Attribution (CC BY) license (https:// creativecommons.org/licenses/by/ $4.0 /)$.
This special issue on "Contemporary Teacher Education: A Global Perspective" contains eleven articles focused on varied current topics in teacher education all over the world. We take a holistic approach to teacher education and argue that the purpose of education is to educate the whole personality of a teacher including cognitive, social, and moral domains [1,2] This kind of approach should be implemented in both pre-service and inservice teacher education. We need more research on teachers' values, beliefs and attitudes that influence their motivation to learn new things and develop in their profession. We also need research on teachers' cognitive and social skills that are important in promoting good teaching and learning. Teachers' skills to meet the needs of different learners and to teach different subjects by integrating and differentiating the subject matter are global challenges [3]. The opportunities and problems related to variety of digital technologies and social media create challenges for teachers to support student learning on different cultures and values with critical minds.

Lifelong learning is one of the aims for twenty-first century teachers. A pedagogically competent teacher pays attention to her students' abilities, gender, prior knowledge, motives, and expectations to make learning meaningful for them [4]. Teamwork and cooperation among teachers, with homes and other institutions are necessary to provide the best possible education for our students [5]. All these aims and demands create pedagogical challenges in teacher education and call for research-based approaches that can be applied in teacher education programs.

Contributors to this collection of eleven articles reflect global issues in teacher educations originating from Australia, Estonia, Finland, England, Portugal, and Sweden. Their articles address the following questions: How can holistic learning be actualized in teacher education? What are the challenges in education of purposeful teachers? How can violent extremism be prevented through education? What kind of teacher feedback is perceived as encouraging by students? How do teachers perceive peer-feedback through electronic portfolios? How content are parents with the amount of digital feedback they get from schools? How do parents perceive the role of a teacher in teacher-parent partnership? What kind of scientific knowledge do science teachers need to provide high-quality science teaching? How do teachers' perceptions and self-efficacy beliefs are related to integrated science education? How relevant teachers find MOOCs in their professional development?

How can teacher education cultivate student teacher learning in becoming competent and agentic teachers?

The research in this special issue is an international collection of studies focusing on the current challenges and possibilities in teacher education. The contributors examine teacher education with theoretical and empirical approaches including both qualitative and quantitative research methods. The studies demonstrate that future teachers need high-level ethical and pedagogical skills in order to cope with the new challenges in education. With the research-based and holistic approach we can educate good teachers for tomorrow's schools. 


\section{References}

1. Tirri, K. Ethical sensitivity in teaching and teacher education. In Encyclopedia of Teacher Educations; Springer: Singapore, 2019.

2. Korthagen, F.A.J. In search of an essence of a good teacher: Towards a more holistic approach in teacher education. Teach. Teach. Educ. 2004, 20, 77-97. [CrossRef]

3. Tirri, K.; Toom, A. Pedagogy in Basic and Higher Education: Current Developments and Challenges. IntechOpen. 2020. Available online: https:/ / www.intechopen.com/books/pedagogy-in-basic-and-higher-education-current-developments-and-challenges (accessed on 30 June 2021).

4. Bundick, M.J.; Tirri, K. Student Perceptions of Teacher Support and Competencies for Fostering Youth Purpose and Positive Youth Development: Perspectives from Two Countries. Appl. Dev. Sci. 2014, 18, 148-162. [CrossRef]

5. Kuusimäki, A.-M.; Uusitalo-Malmivaara, L.; Tirri, K. Parents' and teachers' views on digital communication in Finland. Educ. Res. Int. 2019. [CrossRef] 